\title{
Communication
}

[Comunicação]

\section{Infection by Mycoplasma agalactiae in dairy goat herds in the microregions of Cariri in Paraíba State, Brazil}

[Infecção por Mycoplasma agalactiae em rebanhos caprinos leiteiros nas microrregiões do Cariri na Paraíba]

\author{
D.A. Bandeira ${ }^{1}$, R.S. Castro $^{2}$, E.O. Azevedo ${ }^{3}$, E.R. Nascimento ${ }^{4}$, \\ L.S.S. Melo ${ }^{5}$, C.B. Melo ${ }^{5 *}$
}

${ }^{1}$ EMEPA S.A. - João Pessoa, PB (in memorian)

${ }^{2}$ Departamento de MedicinaVeterinária - UFRPE - Recife, PE

${ }^{3}$ Departamento de Veterinária - UFCG - Patos, PB

${ }^{4}$ Universidade Federal Fluminense - Niterói, RJ

${ }^{5}$ Faculdade de Agronomia e Medicina Veterinária - UnB

Caixa Postal 4508

70910-970 - Brasília, DF

Different species of Mycoplasma cause important infections in goats and sheep, such as pneumonia and mastitis. Goat mycoplasmosis which is caused by several species of Mycoplasma is reported worldwide (Contreras et al., 2003, Ur-Rahman et al., 2006; Adehan et al., 2006). In Brazil, there are reports of Mycoplasma isolation from animals with respiratory and reproductive problems, mastitis, agalactia, and keratoconjunctivitis (Nascimento et al., 1986; Muller et al., 1998; Buzinhani et al., 2007). The first report of Contagious Agalactia of Sheep and Goats (CASG) in Brazil was registered in the State of São Paulo in 1942 (Penha and D'Apice, 1942), in a doe. The disease evolved with agalactia, lameness, emaciation, and death as well as fever, prostration, and anorexia in kids. At necropsy, hyperemic spots were observed in the lung of a kid. A microorganism was isolated from the liver with similar characteristics to that of pleuropneumonia. However, at that time, the identification of the involved Mycoplasma species was not possible.

Azevedo (2005) described mastitis followed by agalactia, polyarthritis, and keratoconjunctivitis in seven outbreaks in Paraíba, Pernambuco, and Rio Grande do Norte states, from August 2001 to
September 2002. In this work, M. agalactiae was isolated and identified as the microorganism responsible for the infection using immunoperoxidase techniques and polymerase chain reaction (PCR).

The importation of exotic goat breeds aiming for genetic improvement of the native herd favored the growth of goat production. However, little emphasis has been given to the control of the infectious diseases, the occurrences of which result in negative and important socioeconomic consequences, with losses and depreciation of the herds. Therefore, the aim of this work was to verify the occurrence of $M$. agalactiae using PCR in 30 goat herds from in 15 municipalities of the microregion of Eastern and Western Cariri, which are located in the middle region of Borborema, Paraíba State, Brazil.

The studied herds were from São Sebastião do Umbuzeiro, São João do Tigre, Zabelê, Prata, Amparo, Monteiro, Prata, Sumé, Serra Branca, Cabaceiras, Boqueirão, Caturité, Taperoá, Santo André, and Gurjão municipalities. Information on mycoplamosis prevalence in goats had not been recorded in that region. The sample size calculation was made according to Thrusfield

Recebido em 15 de janeiro de 2008

Aceito em 2 de setembro de 2008

*Autor para correspondência (corresponding author)

E-mail: cristianomelo@unb.br 
(2004), with four samples for each studied property. Milk samples were collected and analyzed from January and July 2004 and 120 milk samples were collected to search for $M$. agalactiae. For each $2.0 \mathrm{ml}$ of collected milk, 2.0 $\mathrm{ml}$ of a $50 \%$ glycerinated saline solution was added, conditioned in sterile test tubes and sent under refrigeration to the laboratory for the identification of $M$. agalactiae using PCR as described by Azevedo (2005).

Out of 120 milk samples tested, nine (7.5\%) presented DNA amplification of only one fragment with $360 \mathrm{bp}$ (Fig. 1), which were observed in six $(20 \%)$ of the 30 studied herds (Table 1), from Amparo, Santo Andre, and Gurjão municipalities.

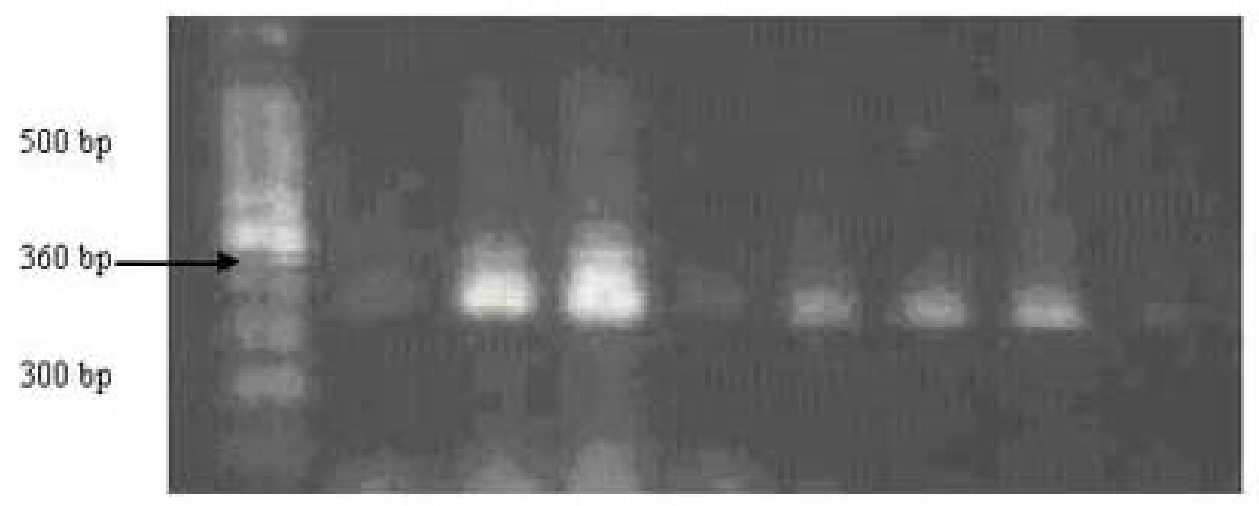

Figure 1. PCR of milk samples collected in 30 goat herds in microregions of Cariri, Paraíba State, Brazil.

Table 1. Results of PCR for M. agalactiae in milk samples of 30 goat herds in microregions of Cariri, Paraíba State, Brazil (2004)

\begin{tabular}{lcccc}
\multicolumn{1}{c}{ Type of sample } & Negative & $\%$ & Positive & $\%$ \\
\hline Individual & 111 & 92.5 & 9 & 7.5 \\
Herd & 24 & 80.0 & 6 & 20.0 \\
\hline
\end{tabular}

The presence of $M$. agalactiae in $20 \%$ of the herds and $7.5 \%$ of the studied animals strengthens the need to include this microorganism in the mastitis and arthritis studies in dairy goat. In Nigeria, Egwu et al. (2001) isolated M. agalactiae, M. capricolum, Acholeplasma laidlawii, $M$. bovis, $M$. putrefaciens, and M. mycoides mycoides LC in goats with clinical and subclinical mastitis.

Mycoplasma agalactiae infection quickly spreads and there is a need to apply a specific, sensitive, and rapid diagnostic procedure for its detection. Several rapid diagnostic methods have been developed for the detection of $M$. agalactiae (González et al., 1995, Tola et al., 1997, Azevedo, 2005). PCR technique is much faster than culture and reduces the time required for diagnosis from several days to five hours (Tola et al., 1997). The similarity among all samples and farms confirmed the presence of $M$. agalactiae in the herds and suggested that the infection in the Brazilian Northeastern herds has a common origin. The used PCR was shown to be adequate for $M$. agalactiae identification, because the nucleotide sequence of the fragment presented $100 \%$ identity with the $r r n$ gene that codifies the $16 \mathrm{~S}$ rRNA protein of $M$. agalactiae (González et al., 1995; Azevedo, 2005).

Mycoplasmosis causes an important impact on the local economy, especially in situations in which the sale of goat milk is the only income. Therefore, small breeders will suffer the most damage by the dissemination of this disease, since they do not have enough financial resources to replace the breeding stock or to implement control procedures (Azevedo, 2005). According to Contreras et al. (2003), clinical mastitis due to mycoplasmas are highly prevalent in some areas and cause financial looses that are incomparable with those caused by other 
intramammary pathogens and the main repercussion of the disease is a dramatic decline in milk production, which may be irreversible in some animals.

Outbreaks of goat mycoplasmosis in Paraiba and Pernambuco states were related to a history of participation in fairs and expositions and introduction of animals from the Brazilian Southeastern and central-western regions. In the state of Rio Grande do Norte, the available information indicated that this disease appeared after the purchase of dairy goats from Paraíba State. The rapid dissemination of $M$. agalactiae, and probably of other infections, has been favored by the intense trade and transit of animals among breeders of these three States (Paraíba, Pernambuco, and Rio Grande do Norte), as well as the participation in collective events, favored by state programs that stimulate goat milk production. Therefore, the presence of $M$. agalactiae strengthens the necessity of including tha research on this microorganism in mastitis and arthritis cases and implementing mycoplasmosis control programs in a combined way with both public and private sectors.

It has been shown that the use of a vaccine will not prevent the presence of mycoplasmas in the herd. Thus in certain epidemiological situations, the vaccine is not a recommended strategy (Pepin et al., 2000; Contreras et al., 2003). Also, the massive use of antibiotics in affected herds is one of the main risk to the health of the consumers (Contreras et al., 2003).

Mycoplasmosis emerges as a disease with the potential for high negative impact on dairy goat breeding in that region. Therefore, it is recommended that the control measures for this disease be applied.

Keywords: goat, mycoplasmosis, milk, CASG

\section{RESUMO}

O objetivo deste trabalho foi verificar a ocorrência de Mycoplasma agalactiae, com o uso da reação em cadeia da polimerase (PCR), em 30 rebanhos caprinos leiteiros nas microrregiões do Cariri Ocidental e Oriental do estado da Paraiba. Das 120 amostras de leite testadas, nove (7,5\%) apresentaram amplificação de apenas um fragmento com $360 \mathrm{pb}$. As amostras que amplificaram este fragmento estavam presentes em 6/30 (20\%) fazendas localizadas nos municipios de Amparo, Santo André e Gurjão.

Palavras-chave: caprino, micoplasmose, leite, agalactia contagiosa

\section{ACKNOWLEDGMENTS}

This work was supported by grants from CNPq. The authors wish to thank Concepta McManus for her suggestions on this manuscript.

\section{REFERENCES}

ADEHAN, R.K.; AJUWAPE, A.T.P.; ADETOSOYE, A.I. et al. Characterization of Mycoplasmas isolated from pneumonic lungs of sheep and goats. Small Rum. Res., v.63, p.44-49, 2006.

AZEVEDO, E.O. Aspectos clínicoepidemiológicos e diagnóstico laboratorial da agalaxia contagiosa dos ovinos e caprinos (ACOC) no Brasil. 2005. 87f. Tese (Doutorado) Departamento de Medicina Veterinária, Universidade Federal Rural de Pernambuco, Recife.
BUZINHANI, M.; METIFFOGO, E; TIMENETSKY, J. Detecção de Mycoplasma spp. e Ureaplasma diversum em vacas com distúrbios reprodutivos. Arq. Bras. Med. Vet. Zootec., v.59, p.1368-1375, 2007.

CONTRERAS, A.; LUENGO, C.; SÁNCHEZ, A. et al. The role of intramammary pathogens in dairy goats. Livest. Prod. Sci., v.79, p.273-283, 2003.

EGWU, G.O.; AMEH, J.A.; ALIYU, M.M. et al. Caprine mycoplasmal mastitis in Nigeria. Small Rum. Res., v.39, p. 87-91, 2001.

GONZÁLEZ, Y.R.C.; BASCUÑANA， C.R.; BÖLSKE, G. et al. In vitro amplification of the 16S rRNA genes from Mycoplasma bovis and Mycoplasma agalactiae by PCR. Vet. Microbiol., v.47, p.183-190, 1995.

MULLER, E.E.; NASCIMENTO, E.R.; METTIFOGO, E. et al. Isolamento de 
Mycoplasma arginini e Actinomyces pyogenes de ovino com pleuropneumonia. Rev. Bras. Med. Vet., v.20, p.118-119, 1998.

NASCIMENTO, E.R.; NASCIMENTO, M.G.F.; FREUND, E.A. et al. Isolation of Mycoplasma mycoides from outbreaks of caprine mycoplasmosis in Brazil. Br. Vet. J., v.142, p.246-249, 1986.

PENHA, A.M.; D' APICE, M. Agalaxia contagiosa das cabras em São Paulo. Arq. Inst. Biol., v.13, p.299-301, 1942.

PEPIN, M.; SANCHIS, R.; ABADIE, G. et al. Experimental vaccination against Mycoplasma agalactiae using an inactivated vaccine.
European Comission, Mycoplasmas of Ruminants: pathogenicity, diagnostics, epidemiology and molecular genetics. Cost Action 826, v.5, p.162-165, 2000.

THURSFIELD, M. Epidemiologia Veterinária. 2. ed. São Paulo: Roca, 2004. 572p.

TOLA, S.; ANGIONI, A.; ROCCHIGIANI, A.M. et al. Detection of Mycoplasma agalactiae in sheep milk samples by polymerase chain reaction. Vet. Microbiol., v.54, p.17-22, 1997.

UR-RAHMAN, S.; SIDDIQUE, M.; RASOOL, M.H. Seroprevalence of Mycoplasma mycoides subspecies capri in ruminants and camel. Small Rum. Res., v.63, p.28-31, 2006. 